\title{
The Operations of the English Fleet, $1648-52$
}

T $\mathbf{N}$ the early days of the Civil War, the fleet had been uniformly on the side of the parliament; but in September 1647, William Batten, commander of the squadron in the Downs, resigned, and a soldier, Colonel Thomas Rainsborough, was appointed in his place. ${ }^{1}$ For some little time there was no aign that the navy resented this interference by the army in matters outside its province, but at length, on 27 May 1648, the outbreak occurred. A mutiny broke out in Rainsborough's flagship, the Constant Reformation, and spread at once to the rest of the squadron. ${ }^{8}$ Rainsborough and the other military officers were put ashore, and a declaration was aigned by the officers of most of the ships demanding the conclusion of a personal treaty with the king, the disbanding of the army, and the reappointment of the earl of Warwick as admiral. This last demand was conceded on 29 May. $^{3}$ Possibly Warwick's return prevented the spread of the mutiny, but it was too late to pacify the original mutineers; these evidently felt they had gone too far to draw back, and accordingly left the Downs for Yarmouth Roads."

For the moment the position of the parliament looked very black. Another ship, the Convertine, ${ }^{5}$ joined the mutineers from the Thames, while two of the three ships at Harwich were known to be in a state of acute disaffection. Thus on the return of the mutinous squadron to the Downs on 8 June it found itself in a very strong position. ${ }^{6}$ A list makes it consist of the eight ships : Constant Reformation 42, Swallow 34, Convertine 34, Antelope 36, Satisfaction 26, Roebuck 14, Crescent 14, and Pelican 12, but apparently the $H$ ind 16 was also there, ${ }^{7}$ since her officers had aigned the declaration, and she was certainly with Rupert later in the year. The mutineers had therefore a force of nine ships with 226 guns.

Against them Warwick could bring only the following ships :

1 The Professional Life and Times of Sir Willian Penn, i. 250-9.

- Calendar of State Papers, Domestic, 1648-9, 87.

- Or Conpertive.

- Calendar of State Papers, Dom., 1648-9, 108, $110-11$.

1 poid 124. 
two that had mutinied and returned to duty, the Warwick 22, and Greyhound 12; three at Harwich, Adventure 38, Tiger 38, and Providence 30, the last two being very untrustworthy; two in the Thames, the Nicodemus 6 and Hunter (ketch); two at Chatham, the Fellowship 28 and Hector 20 ; a total force of nine ships with some 200 guns, ${ }^{8}$ scattered and, to some extent, untrustworthy. Fortunately for the parliament the mutineers were without a leader or a plan ; they missed their chance, left the English coast, and stood over to Helvoetsluys, at the mouth of the Mras in Holland, to put themselves under the orders of the prince of Wales. ${ }^{9}$

Both sides now endeavoured to organize their available resources. The position of the parliament was very difficult, for some of the ships at Portsmouth were disaffected to such an extent that it was proposed to remove their sails to prevent their leaving, ${ }^{10}$ and they were obviously of little use as a reinforcement for Warwick. While things were in this state the new royalist fleet put to sea, with the prince of Wales himself in command and Lord Willoughby of Parham as his vice-admiral. Leaving Helvoetsluys on 17 July, the prince was off Yarmouth on the 22nd ; ${ }^{\mathbf{l}}$ but finding that there was no chance of organizing a local rising, and being refused provisions, he left the next day and took up his position in the Downs. Here he took, or was joined by, the Blackmoor Lady 18, landed a party near Deal on 14 August, and was joined by two fine seamen, Batten and Jordan, in the Constant Warwick 30, from London. ${ }^{12}$ There were now various possibilities as to his future action. He might go to the Isle of Wight in the hope of rescuing the king, he might try and relieve the besieged garrison of Colchester, he might see what could be done in Scotland, or he might enter the Thames in the hope of capturing some of the London trade. ${ }^{13}$ In the end he adopted this last plan and took several prizes, including one large merchantman, the Guinea. This move brought him into contact with Warwick's squadron. On 29 August the two fleets met off what is now Southend, but just as the action was about to begin a heary squall forced both to anchor. The prince of Wales made no further attempt to

- Ibid. Other ahips not yet available were the St. George and Unicorn at Chatham, and the Nonouch, Phoenix, Mary Rase, Robert, Bonaventure, Aarland, Johm, and Lion at Portsmouth or expected there. Mr. Corbett, England in the Mediterranean, i. 186, says, ' Out of 27 vessels in the Downs Warwick secured 18.' He is evidently counting in all the parliamentary ships in the list wherever stationed.

- Warburton, Memoirs of Prince Rupert and the Cavaliers, iii. 249.

10 Cal. of State Papers, Dom., 1648-9, 205.

1 Hannay, Short Hiotory of the Royal Navy, i. 190-1.

"Cal. of Slate Papers, Dom., 1648-9, 220, 243; Sir W. Leird Clowes, The Royal Navy, ii. $80 \mathrm{n}$.

- Warburton, iii. 250. 
engage. He sent to Warwick, summoning him to lower his atandard, and on receiving a refusal left the Thames next day. That night he came upon the Portsmouth squadron at anchor, but made no move to attack them. On 3 September he cast anchor again off Helvoetsluys. ${ }^{14}$

The parliament's available fleet consisted at this time of twenty-one ships, large and small, the St. George, Unicorn, Lion, Phoenix, Nonsuch, Adventure, Tiger, Mary Rose, Providence, Fellowship, Hector, Recovery, Greyhound, Tenth Whelp, Nicodemus, Weymouth Pink, Litty, Hart, Robert, and the ketches Hunter, Doggerboat, and Dolphin. ${ }^{15}$ With this force, after reducing Sandown Castle, the last of the revolted fortresses, Warwick followed the royalists to Holland. On 19 September he anchored outside them, and three days later he summoned the prince of Wales to surrender, a demand which was naturally refused. ${ }^{16}$

About this time Prince Rupert of the Palatinate was appointed admiral of the royalist squadron. For the moment hostilities were prevented by the presence of a Dutch fleet under the great Martin Tromp, but on its withdrawal early in November the difficulties of the new commander became very great, for Warwick was able to move right into the harbour. Rupert was able to protect the bulk of his fleet by means of guns mounted ashore, but he was quite unable to prevent many of his ships from deserting to the enemy. ${ }^{17}$ The Constant Warwick and Crescent had already reverted to the parliament, and now other ships followed their example. These were the Satisfaction, Bind, Love, and others; Warwick's letter of 11 November mentions the Reformation, but this is certainly a mistake. ${ }^{18}$ On 21 November Warwick sailed for England with his prizes.

Rupert's first step was to send a ship to the Isle of Wight to attempt to rescue the king. This proved impossible ; she could only stay a few days without exciting suspicion, and had to return with nothing accomplished. ${ }^{19}$ Ireland now suggested itself as a suitable base, though lack of money made it difficult to put the fleet into a condition to get there. Still by means of pawning not only the jewels of his mother, the queen of Bohemia, but even the guns of one of his ships, the Antelope, Rupert did

\footnotetext{
14 Werburton, iii. 251-2 ; Life of Penn, i. 261-2 ; Cal. of State Papers, Dom., $1648-9,266$; Hannay, i. 182.

1s Life of Penn, i. 263, List of 5 Sept.

11 Laird Clowes, ii. 84 ; Life of Pern, i. 264.

17 Warbarton, iii. 255-65.

14 Cal of Slate Papers, Dom., 1648-9, 324 ; Laird Clowes, ii. 119 ; Life of Penn, i. 277. Mr. Cerr Laughton (in Laird Clowes, ii. $80 \mathrm{n}$ ) gives Truelove instead of Love, bat the latter was certainly taken by Rapert in the Downs and recovered by Warwick later (Cal. of State Papers, Dom., 1648-9, 376).

- Farburton, iii. 266 and 272-3.
} 
manage to get the Guinea 30 and Roebuck 14 to sea early in January 1649. These ships started at once to display that indifference as to the nationality of their victims that proved so characteristic of Rupert's vessels; they returned with an English collier carrying $\mathfrak{f} 800$ in cash and a Hamburg merchantman taken by the Guinea off Yarmouth. Here then were the necessary funds. The collier was sold, the Hamburger fitted out as a warship, and on 21 January Rupert was able to set sail. ${ }^{20}$ His force consisted of eight ships, the Constant Reformation 42, Convertine 34, Swallow 34, Roebuck 14, Pelican 12, and the prizes Guinea 30, James (formerly the Exchange of Ipswich), and Charles (the exHamburger). ${ }^{21}$ Two ships were left behind, the Blackmoor Lady 18 and the Antelope 36. The first joined him later, but the second never left Helvoetsluys, being burnt there in June by a party from the Happy Entrance 32. ${ }^{22}$ With Rupert there sailed three Dutch East Indiamen, though whether as convoyers or convoyed is not clear. In the Downs lay the small ' winter guard' under Moulton in the St. George 42, with the Happy Entrance 32, Constant Warwick 30, Satisfaction 26, and perhaps one or two others. On Rupert's approach Moulton withdrew under the forts ; the Satisfaction went aground, but the royalists made no attack. They proceeded without delay to the harbour of Kinsale in county Cork, where the adhesion of a miscellaneous collection of Munster pirates and Dunkirkers brought their force up to twenty-eight ships of various kinds.

With such 'a force Rupert was likely' to be a serious antagonist. Fortunately for the parliament the execution of King Charles I on 30 January 1649 left time for more attention to be paid to naval affairs. Warwick was dismissed from his post as admiral on 22 February, and the famous 'generals at sea', Popham, Blake, and Deane,.were appointed in his stead.24 For some time, however, Rupert was left to be dealt with by Ayscue and Penn on the western station. Several of his ships were taken, but he was. in no way paralysed, and he was able in March to send five ships to relieve the royalists in the Scilly Isles. ${ }^{25}$ This roused the parliament to strong measures. Every possible ship was fitted out, and on 21 May the generals arrived off Kinsale with a large fleet. ${ }^{26}$

The materials for the naval history of the summer of 1649 are scanty, and often mutually inconsistent. Still some kind of a narrative may. be formed. Directly on the arrival of the

20 Warburton, iii. 273-80.',

21 Laird Clower, ii. $11 \theta$.

- Cal. of State Papers,-Dom,; 1649-60, 105 and 206.

2Hist. MSS. Comm. Report 18, App. 1, 509-10.

14 Life of Penn, i. 288-9.

16 Leybourne:Popham MSS. (Hiöt. MSS. Comm. 1899), 11.

31 Ibid. 13. 
fleet off Kinsale, Popham returned to London, taking orders on the way to Ayscue and Penn to join the generals with reinforcements. ${ }^{27}$ A few days later, on 31 May, heavy weather drove off the blockaders and kept them in Milford Haven for some time, but on 20 June they returned to their post and found that Rupert was still there. ${ }^{28}$ Orders now arrived for Deane to see about the transport of the army to Ireland, and sailing to Plymouth in the Charles he was there from 3 July to 8 August. ${ }^{29}$ He then proceeded to Milford, embarked the army, and sailed on the 13th, Cromwell having left for Dublin the day before with thirty ships. After an unsuccessful attempt to attack Kinsale directly, Deane arrived at Dublin on August 23 with eighty-four ships, and added his forces to Cromwell's. ${ }^{30}$ Rupert's position became now more and more difficult as the parliamentary army gradually succeeded in establishing its authority in districts nearer and nearer to his place of refuge. Besides, not a few of his ships were captured by the blockading fleets during this period. On 14 February the Mary Antrim was taken by the Nonsuch, and about the same time the London and Mary and Joseph were taken by the Tiger and Nonsuch. ${ }^{31}$ Returning from the expedition to the Scillies the Charles was captured by the Leopard and Constant Warwick, and in April or May the Guinea, Thomas, and Fame of Waterford shared her fate. ${ }^{32}$ Finally in June or early in July the Santa Tresera (or Teresa) was taken by the Garland and Nonsuch, apparently on her return from a fruitless voyage to Holland to fetch the prince of Wales.33 After this the blockade settled down; Rupert's ships stayed in port, and captures ceased.

The Irish coast was not the only scene of naval activity at this time. Before going to Ireland, Popham had been in command in the Downs to act against Dunkirk and Irish pirates, ${ }^{34}$ and had also been sent to the Scillies to check Rupert's depredations in those waters. In June it was necessary to give convoy up the Channel, while in the same month the Adventure, an Irish pirate, was taken in the North Sea by the Tiger. ${ }^{35}$ In August Popham was doing convoy work in the North Sea till the news

"Leybourne-Popham MSS. 17.

2. Life of Richard Deane, 404.

* Leybourne-Popham MSS. 18 ; Life of Pent i. 291.

2o Leybourne-Popham MSS., 24-5, 30 ; Life of Deane, 406.

"Cal. of State Papers, Dom., 1649-50, 71 ; Hist. MSS. Comm. Rcport Iy, App. 1, 500-10, where it is eaid that she was taken by Penn in the Lion, but only on hearsay evidence. She was renamed Tiger's Whelp (Cal. of State Papers, Dom., 1649-50, 75), and lost near Dublin in September (Leybourne-Popham MSS., 42).

is Warburton, iii. 289-80; Cal. of State Papers, Dom., 1649-50, 150, 173, 255.

2 Leybourne-Popham MSS., 21 ; Laird Clowes, ii. 120.

a Leybourne-Popham MSS., 11.

"Cal. of State Papers, Dom., 1649-60, 193. She was renamed Jermyn(Cal. of State Papers, Dorn., Admiralty Warrante, July 9). 
of the presence of the prince of Wales in Jersey caused Parliament to send their only available squadron thither. On 14 September Popham left the Downs, and three days later he was at Guernsey. No enemies appesred, he could do hothing ashore, and on 1 October, after losing the Crescent at St. Sampson's, he started for home."e. Arriving in the Downs on the 3rd, he found a large portion of the Irish fleet sent bock for the winter, though Blake was still off Kinsale with five good ships.

At last Rupert's chance came. A gale drove the blockaders from their station, and towards the end of October ${ }^{37}$ he put to sea with eight ships, steering for Lisbon, where he was already assured of a friendly reception. ${ }^{\text {ss }}$ Lack of stores and men had obliged him to leave three ships, the Roebuck, James, and another, to be captured by the parliamentary army, but on his way south he had the good fortune to take five prizes, so that on his arrival in the Tagus about the middle of November he had a fleet of thirteen ships: five original mutineers, the Constant Reformation 42, Convertine 34, Swallow 34, Blackmoor Lady 18, and Pelican 12, with the Black Knight (or Black Prince) 42, Roebuck (prize) 34, Scott, Mary, Second Charles, Henry, and two others. ${ }^{39}$ Taking full advantage of his opportunities, Rupert set to work to give his ships a thorough refit. Unfortunately for him, just as he was ready for sea, a strong parliamentary fleet appeared. This was on 10 March $1650 .^{.0}$

As soon as it was known that Rupert had gone to Lisbon the council of state had decided to send a fleet after him. There was much delay in its fitting out, but at last Blake was able to leave Portsmouth on 2 March 1650 with sixteen vessels, the George 50, Leopard 48, Bonaventure 44, Happy. Entrance 40, Adventure 36, Assurance 36, Expedition 26, Providence 27, Tiger 32, John 32, Constant Warwick 32, and Merchant Frigate 28, with the fireships Cygnet 8 and Tenth Whelp 8, and the ketches William and Patrick.11 On arriving at the mouth of the Tagus, Blake was about to enter, but was received with shots from the forts ; ${ }^{42}$ he therefore anchored in Cascaes Bay to the north. A demand that Rupert should be ordered out met with a refusal, 43 but leave was given for the parliamentary fleet to move in as far as Oeiras in the event of heary weather, though only on condition that it should withdraw as soon as the weather improved.

26 Leyboume-Popham MSS., 26-32.

" Heath, Chronicle (2nd ed.), 254, вays 24 October.

2s Prince Rupert at Liston (Camden Misc. x), 8-11.

2 Compiled from Warburton. Sce also Prince Rupert at Libbon, 2.

“" Warburton, iii. 301.

12 Laind Clowes, ii. 125. Originally it was intended to send five ships only (Life of Penn, i. 283).

Warburton, $l . c$. in Gardiner, Hist. of the Commonroealth, i. 331 . 
On 5 April two French warships arrived, one of 50 guns and the other of 28. Knowing nothing of Blake's presence, they sailed into his fleet and were detained, though they were subsequently released." Relations with France were, as a matter of fact, very insecure. Apart from the known friendliness of the French court to the exiled prince of Wales, now de jure Charles II, evidence had been given of more definite hostility to the English in general; complaints had been received in February that eight Levant traders had been taken in the Mediterranean, not by pirates or even privateers, but by regular French men-of-war. ${ }^{45}$ In these circumstances it was desirable to reinforce the English fleet off Lisbon. Accordingly, on 15 May, Popham sailed for Portugal with a second squadron, ${ }^{16}$ consisting of the Resolution 68, Andrew 42, Phoenix 36, Satisfaction 26, and the merchantmen Great Lewis, Merchant, Hercules, and America or James."7

While these ships were on their way out the Portuguese Brazil fleet sailed. Blake at once stopped them, impressed the nine English ships among them, and added them to his own fleet; his orders would not permit of his interfering with the actual Portuguese vessels. ${ }^{48}$ This was on 21 May. Five days later Popham joined him, bringing extended orders. The generals were now authorized to attack Rupert anywhere. If Portugal opposed this, they were to capture Portuguese ships, and they were in any event to begin the capture of French ships at once, merchantmen or men-of-war. ${ }^{49}$ At the same time Deane, in the home fleet, was ordered to attack any French ships he might meet. ${ }^{50}$ Attempts were made to negotiate. Vane, the parliament's envoy, was sent ashore on 27 May, but returned after four days with nothing accomplished. ${ }^{51}$ Blake's original ships were now short of supplies, especially of drink; he therefore shifted his flag from the George to the Resolution, Popham's flagship, and detached his rear-admiral, Captain Badiley, to Cadiz on 14 June with the eight ships, Happy Entrance, George, Leopard, Adventure, Assurance, Merchant, Tenth Whelp, and one of the ketches. ${ }^{52}$ At the same time the Constant

“" Warburton, iii. 304 ; Laird Clowes, ii. 126 ; Corbett, England in the Medicerranean, i. 208.

4 Cal. of Slate Papers, Dom., 1649-50, 11-12, 16-17.

"Cal. of State Papers, Dom., 1650, 61 ; Leybourne-Popham MSS., 64.

"Thurloe, State Papers, i. 144-5 ; Life of Penn, i. 298 ; Leybourne-Popham MSS., l.e. In the first two references the America is named ; but Popham's own narrative says the James, and also mentions a storeship.

4 Cal. of Stale Papers, Dom., 1649-50, 428; Warburton, iii. 306.

40 Leybourne-Popham MSS., 65 ; Corbett, i. 208-9. is Life of Penn, i. 302.

st Leybourne-Popham HSS., l. e.

"Leybourne-Popham MSS., 66-7; Letters and Papers relating to the First Dutch War, i. 2 (Navy Records Boa.). 
Warwick was sent home with dispatches, and early in July it became necessary to send the Tiger, Providence, and Cygnet to Bayonne for drink.

On 11 and 12 July the Phoenix took two Dutch ships which were trying to enter Lisbon. Four days later the Assurance, the first of Badiley's squadron, rejoined the fleet. She reported that a squadron of four French ships had been found at anchor at Lagos. ${ }^{54}$ Three had escaped, but the fourth, a ship of thirty-six guns, had been brought to action by the Adventure 36, and taken after two hours' fighting, so much damaged that she had sunk soon after the surrender. She also reported that the rest of Badiley's ships would follow shortly. They were badly wanted. Of a force of twenty-four ships, Badiley had taken eight, one had gone to England and three to Bayonne. The Cygnet had rejoined, but the Providence on returning had again been detached, and the America had also been sent away for water to the Burlings. ${ }^{56}$

Meanwhile their enemies were moving. ${ }^{56}$ On 21 July they began to assemble in Oeiras Bay, and on the 26th the combined force of French, Portuguese, and royalist ships got under way. Altogether they had twenty-six warships and eighteen merchantmen, while the parliament's fleet, even after being joined by the Tiger on the 23rd, consisted only of twelve men-of-war, one fireship, one ketch, and nine Brazil merchantmen. Furthermore, two of the warships, the Hercules and Assurance, were out at sea -probably looking for Badiley-and took no part in the subsequent action. The allies had, therefore, a superiority of about two to one, but in spite of this they accomplished nothing whatever. It was between 9 and 10 in the morning of 26 July when Rupert and his friends were seen to be on the move. The English fleet at once weighed anchor and lay to with the wind ESE., waiting to be attacked. In the van was the French flagship with four fireships; about a mile astern came Rupert in the Constant Reformation; further astern and well out of harm's way was the Portuguese contingent. ${ }^{57}$ The wind veered to south, whereupon the parliamentary fleet went about and got to windward. The enemy also tacked and the English bore up to attack. The Resolution and Phoenix opened fire on the French admiral till he bore away, followed by Rupert and the rest of the allies. At first they headed for Cape Espichel, but eventually finding that they could not weather it, they tacked, steered north, and anchored off the North Cachopo shoal at the mouth of the Tagus. The generals followed till nightfall and then stood off. Next

53 Hid. MSS. Combm. Report 18, App. 1, 531 ; Leybourne-Popham MSS., 70.

st Letters and Papers relating to the First Dutch War, i. 2-4.

ss Leybourne-Popham MSS., 70-2.

se Hiat. MSS. Comm. Report 18, App. 1, 531 et seq.

57 Warburtog, iii. 309. 
morning the allies were seen to be close under the Cascaes forts. Lack of wind prevented an attack; all that could be done was to send the Assurance in after dark to keep them employed.

The morning of the 28th was foggy and almost calm. The combined fleet made sail, and this brought Popham and Blake in close enough for the forts to open fire on them. A light breeze from the south gave the allies the weather gage, but they made no attack. Finally, as evening drew in some six or more sail were sighted in the offing. The situation of the parliamentary fleet was somewhat delicate; if the strangers were French, as was quite probable, a withdrawal would be almost imperative, while if they were Badiley's squadron all would be well. During the night they stood towards the new-comers to find at daybreak on the 29th that they were indeed Badiley's ships. Now, howover, ready as they were to engage, a head wind made the return a slow process, and when, on the morning of $30 \mathrm{July}$, they were again off the mouth of the Tagus, it was only to discover that Rupert and his allies had gone up the river and that the blockade must begin again. As before, it soon became impossible to keep the blockading fleet at full strength. The detached ships rejoined, the Constant Warwick came back from England with orders for a strict blockade, but after about a fortnight the Brazil ships were found unfit to remain at sea and had to be sent home. ${ }^{58}$ This was not all; on 3 September Popham left the fleet with the Resolution and seven other ships to refit at Cadiz and thence return to England. It is, at least, fairly certain that Popham went with this detachment; he does not sign the next dispatch, and he was, we know, in London on 24 October. ${ }^{58}$

Blake was thus left off Lisbon with ten ships, and, as in July, Rupert tried to take advantage of the temporary weakness of the blockaders. On 7 September, under cover of a fog, the royelist ships and their Portuguese allies left the harbour. Apparently the French took no part in this movement,; certainly Gibson in his memoirs speaks of 'several French ships of war', but he is by no means trustworthy as to details, and neither Blake's report nor the royalist account ${ }^{61}$ makes any mention of the French. Again the Portuguese failed to support Rupert properly. Still at 4 p.m. Blake in the George 50, with only the Phoenix 36 and Expedition 26 in. company, and the rest of his fleet out of sight in the fog, found himself unexpectedly confronted by thirtysix sail of the enemy. Rupert was leading in the Constant

- Laird Clowes, ii. 129 ; Cal. of Slate Papers, Dom., 1650, October 12.

to Whitelock, Menorials, 459.

- Letters and Papers relating to the Fira Dutch. War, i. 13.

a Warburton, iii. 309. This account hopelessly confuses this action with that of July 26. 
Reformation 42, and he and Blake stood towards one another on opposite tacks. The George clearly could not weather her opponent, but rather than pass to leeward in the position of the inferior Blake chose to run the risk of a collision and held on. He was justified ; Rupert gave way, bore up and went to leeward to receive a broadside from each of his three enemies. His foretopmast came down and he bore away for support, but the return of the fog put an end to the fighting.

Blake stood off to collect his ships. Next day he met them, but Rupert had then returned to shelter. However, a week later, on 14 September, there appeared twenty-three sail of the Portuguese Brazil fleet. At once the English attacked, in spite of a heavy sea which made it impossible to use the lower-deck guns. The Portuguese admiral got away, but the George captured the rear-admiral, the Assurance took and burnt the vice-admiral, and there were six other prizes. Still Blake's fleet was in a bad state, and a refit was urgent; he therefore took his prizes to Cadiz, where he could obtain the much-needed supplies and equipment, and where the Spanish fleet received him with honours. From Cadiz he sent home another detachment. On 14 October Badiley left for England with five ships, the Happy Entrance, George, Assurance, Hercules, and Merchant, convoying the captured Brazil ships Peter, Anthony, Lady Remidia, and Good Shepherd, the three others being unseaworthy. Badiley reached the Downs on 2 November. ${ }^{62}$ He brought with him Blake's dispatch, in which, after describing the events of the past two and a half months, he expressed his intention of remaining in southern waters with the seven ships left to him, the Leopard 48 (repairing masts and not at once available), Bonaventure 44, Phoenix 36, Elizabeth 36 (a new arrival), Constant Warwick 32, John 32, and Expedition 26.

Meanwhile Rupert had been to sea to look for Blake and attempt the recovery of the Brazil ships ${ }^{68}$ He failed in his quest, and on returning found the Portuguese court less favourably disposed to him. It had, in fact, become obvious that Rupert was too expensive a guest; so the king of Portugal having, as the royalist account puts it, 'no further use for our ships, victualled our fleet', and in effect asked Rupert to leave. He did so on 12 October with the Constant Reformation 42, Black Prince 42, Swallow 34, Roebuck 34, Second Charles, and Henry. These were all he could equip; the Convertine was left in the Tagus and handed over to the parliament later, the Blackmoor Lady was sold there; the fate of the others is unknown, but they were

- Bediley's report, Hist. MSS. Comm. Report 13, App. 1, 641 ; Spalding, Life and Times of Richard Badiley, p. 49 n.

- Warburton, iii. 313. 
presumably sold or broken up in Lisbon. Leaving the Tagus, Rupert waited off the Portuguese coast for a French warship which failed to appear; he must during this time have been fairly close to Badiley's squadron.

Blake, too, got to sea about the same time. On 15 October the Hopewell, from England with orders, found him busy refitting in Cadiz. Judging from their effect the general purport of these orders must have been to recommend vigorous action against the French. On receiving them Blake put to sea in the Phoenix with three other ships and steered for the Straits of Gibraltar. Here on 20 October he met and captured a French ship. As there has been much discussion over the circumstances of this capture it may be as well to examine the evidence in some detail. Blake's own report ${ }^{64}$ says that the Frenchman 'after some dispute yielded upon quarter'. Seltonsall, captain of the John, merely records the fact of the capture, ${ }^{65}$ though very likely the $J o h n$ was not actually present. Whitelock, on 29 November 1650, says: 'after some hours' fight took her and brought her into Cadiz', but on 16 January 1651 he modifies the story and gives a second version to the effect that the captain of the French ship was summoned on board the Phoenix, and that, on his refusing to surrender, Blake told him to go back and fight it out, whereupon he did so, only to have to give in after a two hours' fight. This is the story described by the late Sir John Laughton as ' evidently absurd in every particular', and by Mr. Carr Laughton as 'wildly improbable'. It is, however, confirmed to a great extent by more-recent evidence in Gibsòn's reminiscences. ${ }^{.6}$ Gibson's memory for details was certainly faulty, but since there would have been no point in his telling the story if it were not for its picturesque side, it seems reasonable to accept his account. According to him the French captain supposed from the fact of her flying Blake's flag that the Phoenix must be a powerful ship suitable for an admiral's flagship. He therefore came on board prepared to surrender, but on finding his opponent much weaker than he had expected, began to suggest that he had been tricked. Blake then sent him back to his ship to fight it out, his crew refused duty, and he had to surrender after all. Here we see that there was no fighting, so that the term 'dispute ' in Blake's report must be taken in a moral, not in a physical sense. In this Gibson is corroborated by French accounts. In the instructions given to Gentillot when proceeding to England to demand satisfaction for this and similar seizures it is expressly mentioned that there was no fighting. ${ }^{\circ}$ This authority also

\footnotetext{
4 Hist. MSS. Comm. Report 18, App. 1, 538-8.

as 1bid. 543 .

" Letters and Papers relating to the First Dutch WFar, i. 7-8.

"Guizot, Hist. de la République anglaise, i, App. rvii, 165.
} 
states that the ship was the $J$ ules, ${ }^{68}$ commanded by the Chevalier de la Lande, one of the ships mentioned by Jal as having been acting against Bordeaux in the previous winter. Blake in his report also gives the name of her captain as Lalande, and says he was 'brother to him that was sunk by the Adventure frigate', but here Gentillot's orders contradict him, since the captain of that vessel is given as the Chevalier de Fonteny.

It may be as well at this point to mention some cases of fighting between French and English ships nearer home. Jal in his Abraham du Quesne ${ }^{69}$ gives the French story of one of these actions. Du Quesne on his way from Havre to Bordeaux with five ships is said to have met an English squadron near Jersey and to have been severely wounded in the action that followed, but to have brought his ships safely to their destination ; while another account, also reproduced by Jal, says that he lost one ship captured and three sunk, and only escaped with the fifth, his flagship. Jal proves that Du Quesne's squadron certainly reached Bordeaux; the second account must therefore be exaggerated, but from the extracts which he gives it seems doubtful whether it consisted of four or five ships, so that one may have been lost on the way. Other authorities tend to confirm this view. In the instructions to Gentillot ${ }^{70}$ one of the grounds of complaint is 'the battle with Turenne's squadron proceeding on H.M.'s service to the Bordeaux river in which the frigate La Charite was taken'. From English sources ${ }^{71}$ we know that the Charite of Havre was taken near Cape Hogue by the Nonsuch 36, Captain Mildmay, assisted by an armed merchantman. The affair took place on 12 August, and after seven hours' fighting, chiefly between the Nonsuch and the French flagship, the Charite, in which was the French third in command, was taken in an attempt to support her chief; the French squadron consisted of five ships. Whitelock ${ }^{72}$ says the captured ship carried sixteen guns. There seems little doubt that this is the action to which Jal refers.

The Fairfax 52, a new ship, was concerned in another action or possibly two. Whitelock records the fact in July ${ }^{73}$ that. this ship had been engaged by three French warships, but had beaten them off and reached Plymouth in spite of heavy losses and much damage. A month later ${ }^{24}$ he states that the Fairfax had fought three Frenchmen, and that they had only escaped

a The Hollandeche Hercurius, 1651 (January), p. 7, calls her the Julius Masarini 46. The Swedish ship Jules 32 was given to Mazarin in 1648 : Zettersten, Suenska Flottans Historia, ij. 316. This is evidently the same ship. She was added to the English Navy as the Success 40.

i. 186. "Guizot, wbi supra. $\quad "$ Cal. of State Papers, Dom., 1650, $307,312-13$.

1216 August 1650.

1226 July 1650.

14 28 August 1650.

VOL. XXXI.—NO. OXXIII. 
her by keeping close inshore near Falmouth. This may refer to a second fight, or may be simply another version of the first.

In southern waters, Blake, after taking the Jules on 20 October, returned to Cadiz with his prize. This left the way clear for Rupert to enter the Mediterranean. He soon did so. He had, as has been mentioned, left the Tagus on 12 October, but had waited some days for the expected French ship before starting to work south; had it not been for this delay he must have met Blake in the Straits. Off the Andalusian coast he took two English Malaga merchantmen, while the Second Charles left the fleet in chase of another. After waiting a vain for her to rejoin, Rupert shaped a course for the Straits of Gibraltar. ${ }^{76}$ He put into Tetuan Roads to look for the expected Frenchman, but had to leave for the Spanish coast without her. Off Estepona he made an unsuccessful attack on an English ship, and on 26 October failed in an attempt on the English merchantmen in Malaga.

The news of this attack was passed on at once to Blake at Codiz. ${ }^{76}$ Leaving the Leopard and his prize (now named Success), he put to sea with his other six ships and was off Malaga on 30 October. Meanwhile, Rupert had moved eastward some twenty miles to Velez Malaga, where he found a number of English merchantmen. ${ }^{77}$ In spite of the refusal of the Spanish authorities to allow any attack, Rupert waited two days, and was just preparing a fireship when the merchantmen were destroyed by their own crews. At Montril, thirty miles further east, the royalist fleet destroyed three merchantmen run ashore and abandoned by their crews. This was practically their last success. Between Cape Gata and Cape Palos the Second Charles returned to the fleet with her prize, both being in such a leaky state that they had to be detached for repairs; Formentera, the southernmost of the Balearic Islands, was appointed as a general rendezvous. Blake was, however, close behind. On 2 November he took another French ship of twenty guns off Cape Gata, and next day the Roebuck 34 of Rupert's squadron fell into his hands near Cape Palos. The same night he chased the Henry and Second Charles with the prizes William of London and Malagonian into Carthagena, while a fifth ship, the Black Prince 42, was driven ashore outside the harbour by the John 32, and burnt by her own crew. Following into the harbour Blake demanded the surrender of the royalist ships. It is uncertain what happened, but the result was that on 5 November the four ships went ashore and were wrecked, probably in an attempt to escape, though the royalist account states that they were destroyed by

7. Warbarton, iii. 314.

7. Hit. MSS. Comm. Report 18, App. 1, 538-9.

"Warburton, l. c. 
their own crews, excepting the Henry, which was surrendered through treachery. Be this as it may, none of the ships saw any further service on either side. ${ }^{78}$

The chief of the royalist fleet was still at large, and on $\theta$ November Blake put to sea again to look for him, leaving at Carthagena the John and two French prizes. Separated from their fleet by hesvy weather, Rupert in the Constant Reformation, and his brother Maurice in the Swallow, were the only survivors of the fugitive squadron. Driven out to sea, they had met a large English merchantman, the Marmaduke, and had taken her after a chase lasting all 5 November, and an action all the morning of the 6th. Returning to Formentera and finding no one there, Rupert left orders for a second rendezvous at Cagliari, ${ }^{7 \theta}$ but after another spell of bad weather which drove him to Sicily, he decided not to wait for the rest of his fleet, and sailed with the Constant Reformation, Swallow, and Marmaduke to Toulon, where, although not received with open arms, he was at least able to refit in safety. ${ }^{80}$

The news of Rupert's escape from Lisbon had been a great blow to the English government, and at first their anger was turned on Blake. On 2 November orders were sent to him to the effect that Penn was being dispatched to the Mediterranean as commander-in-chief, and that on meeting him he was to hand over some of his smaller ships to his successor and to bring the rest home. ${ }^{81}$ Three weeks later Penn was appointed to command a squadron of eight ships : the Fairfax 52, Centurion 36, Adventure 36, Foresight 36, Pelican 36, Assurance 36, Nonsuch 36 and Star 22. However, when he left Spithead on 30 November it was with a diminished squadron of only five ships: the Centurion 36, Swiftsure 36, Foresight 36, Pelican 36 and Guinea $30 .^{82}$ On reaching Felmouth he received fresh instructions. The government had received Blake's report from Malaga, and, seeing that his recall would be a mistake, they sent him orders to stay where he was. ${ }^{83}$

Acting under his new instructions, Penn left Falmouth on 20 December for the Azores, in the hope of intercepting the homeward-bound Brazil fleet. ${ }^{84}$ Three days later the Swiftoure was found to be so leaky that she had to be sent home with the Guinea as escort, but pressing on with his other three ships Penn took a Brazil-man, the Nostra Señora, on 13 January 1651. He was, however, just too late; when he reached the Azores 'four days later, it was only to learn that his prize had been one of the last

"Warburton, iii. 312, 317-8; Cal. of State Papers, Dom., 1651, 21 ; Heath (8econd ed.), 275 ; Hir. HSS. Comm. Report 18, App. 1, 538-40, 543, 549.

" Ibid., 529 .

Warburton, iii. 317-20.

- Life of Pern, i. 310-11.

Ibid. 311, 317 .

- Cal of State Papers, Dom., 1660-1, 468 ; Corbett, i. 222.

- Life of Penn, i. 319 et seq. 
of the fleet, and that the rest had escaped him. Furthermore, now that it became the obvious course to move towards the Portuguese or Spanish coast, he was pinned to the Azores by strong easterly winds. On 22 January Lawson, his vice-admiral, arrived with the Fairfax 52 and Star 22. He and Penn thereupon exchanged flagships, and on 3 February Lawson, in the Centurion, took the French Couronne de France 24, a Havre merchantman laden with corn. At last Penn did get away from the Azores, but on 18 February he met a Dutch convoy escorted by four or five warships under de Witte, and from him he heard that Blake had gone home in accordance with his first orders. This was a fact; he reached England early in February, to find a good reception awaiting him, and eventually to receive a grant of $\mathfrak{f 1 , 0 0 0}$ with the thanks of parliament for his services.

Penn went on towards the Portuguese coast. On 21 February he met the Assurance 36, commanded by Blake's brother Benjamin, who had brought out new orders to Vigo, in company with the Adventure 36, and had in the meantime taken a Portuguese ship of 28 guns from Brazil. ${ }^{85}$ Finding that Captain Blake did not know the contents of the orders, Penn sent him back to Vigo to fetch them, but on the 23rd, on meeting Captain Ball in the Adventure, he heard that he was ta go into the Mediterranean to act under Blake's orders. Next day further instructions arrived, brought by Captain Hall, who had been put in charge of a second squadron, organized for the express purpose of convoying merchantmen through the Mediterranean. Hall had left the Downs on 14 February, with the Triumph 52, Tiger 36, and the merchantmen Trade's Increase 44, Lion 44, Hopeful Luke 44, Angel 30, and Anthony Bonaventure 30. ${ }^{86}$ He made it clear to Penn that both fleets were to enter the Mediterranean as soon as possible, and proceeded to Cadiz, where he arrived on 28 February, followed next day by Penn. Hall left for the Straits on 13 March, Penn on the 29th. The Assurance had rejoined and the Nonsuch 36 arrived from England, so that at last he was in command of the fleet originally intended for him. He was off Malaga on the 30th, and at Alicante from 14 to 17 April. Soon after this he mot and captured the Great Alexander ${ }^{87}$ of Toulon, apparently a warship, though at present laden with sugar and carrying only 32 guns instead of 44. Finding her unseaworthy, he took her to Iviza, in the Balearic Islands, and persuaded the Spanish governor to look after her, landed his prisoners in Majorca on

4s Letters and Papers relating to the First Dutch War, i. 6. "L Life of Penn, i. 312.

"7 Called Great Alexandria as well as Great Alesander (Penn, i. 331, 390). A French ship, Alexander the Great (Alexandre le Grand), from Lisbon, was taken by the English about this time and is probably the same ship (Hist. MSS. Comm. Repori 18, App. 1, 572, 604.) 
1 May, and then cruised off and on near Minorca, waiting for news of the enemy.

Rupert had meanwhile been busy refitting and reorganizing his squadron. He repaired the Constant Reformation, Swallow, and Marmaduke, now called Revenge of Whitehall, bought the Jeremy and renamed her Honest Seaman, and was joined from Marseilles by a Captain Craven with his ship Speedwell, which had her name changed to Loyal Subject. With these five ships ' he fixed his resolution to take revenge on the Spaniard', but first set to work to get Penn out of the way by spreading reports that he was going eastward. ${ }^{88}$ These had the desired effect. On 5 May Penn decided to move to the southern end of Sardinia. Here he arrived on the 7 th, and the same day Rupert left Toulon, but steering south instead of east. Penn of course knew nothing of this, and after meeting three English merchantmen, and sending them to call for the Great Alexander and escort her home, he steered south for the African coast in the hope of intercepting Rupert if he should try to enter the eastern Mediterranean. ${ }^{89}$ On 19 May he turned northwards again, to hear from a Spanish fleet of 14 ships from Naples that Rupert was at sea. At Leghorn, on the 25th, he was told that Rupert had left Toulon on the 7th, steering east; he therefore left on the 27th for Sicily in the hope of catching him. After five days at Trapani, where after some discussion he got supplies, he left for Cape Bon, the north-eastern point of Tunis. In this neighbourhood he took the French St. Peter 12, and after victualling at Bizerta took the St. Spirito 8. His next supplies he obtained at Goletta, the port of Tunis, and shortly afterwards ceptured two more small French ships. At this point the Tunisians refused him any more supplies, so that he was obliged to move to Sicily. After cruising for a week to the westward of that island he touched at Malta on 25 July and reached Messina on the 29th. Here, at last, he received definite news that Rupert had been seen off Cadiz and that he had failed in his search..$^{00}$

As a matter of fact Rupert was now in the Azores. He had sailed south from Toulon as far as the African coast, and had then gone west. Just outside the Straits he had taken a Genoese ship, and had followed this by the capture of a Spaniard off Cadiz. Thence he had gone to Madeira, but had failed to persuade his half-mutinous followers to accompany him to the West Indies. He had instead visited the Canaries and finally reached the Azores on 25 July. ${ }^{91}$

Penn seems to have seen no reason for hurry in his pursuit.

"Warburton, iii. 321-5; Life of Penn, i. 338.

- Life of Penn, i. 335 et seq.

10 Ibid. 355.

91 Warburton, -نิi. 531. 
He did indeed leave Messina on 30 July, but he spent a week at Cagliari, and afterwards put into Majorca and Formentera.. On 27 August he met two Dutch ships under de Witte, and received from them the false news that they had seen Rupert on 30 June off the Lizard, steering up Channel. Penn next visited Malaga, and finally arrived in the Straits on 9 September. One thing seemed fairly certain: Rupert was not in the Mediterranean. Penn, therefore, settled down to prevent his return, and at the same time to take such French prizes as luck might send him. ${ }^{\text {gs }}$

Rupert was no longer a very formidable enemy, and soon his force was still further reduced. Directly after his arrival in the Azores he took a large Spanish ship, his only success as it proved. In one of his prizes, the St. Michael 32, the original crew managed to recapture their ship and sailed for England. A little later, in a gale on 30 September, the Constant Reformation, old and leaky, sank with 333 men of her crew, only Rupert and a very few others being saved. The rest of the fleet managed to reach Fayal, but lost the Loyal Subject, which was wrecked there on 19 October. ${ }^{93}$ Finally, an attempt on a Spanish ship in Pico Roads led to friction with the Portuguese. On 7 December the remaining royalists put to sea; on the 26th they anchored off Cape Blanco on the African coast, about half-way between the Canaries and the Cape Verde Islands; four days later they entered the harbour on the south side of the cape.

Rupert now disappears from the scene as far as European waters are concerned, but it seems best to follow his cruise to its end in some detail, before returning to deal with events nearer home. He stayed a month at Cape Blanco, repairing his ships and making up for his enforced rest from semi-piratical operations at sea by raids of a very similar character on the neighbouring tribes ashore. On 26 January he sailed for the Cape Verde Islands; he spent a fortnight at Boavista and a fow days at St. Iago, and reached the Gambia River on 27 February. Here he took two ships; one Spanish and one English ; the latter, called the Friendship, he renamed Defiance. He left again for the Cape Verde Islands on $29 \mathrm{March}$; off Mayo Island on 5 April he took an English ship of 18 guns, and on the 18th two others, but at the same time he lost the Revenge of Whitehall, seized by a handful of her crew who held to the parliament and taken to England. ${ }^{94}$

On 9 May Rupert left for the West Indies, and on the 29th he resched St. Vincent. Sailing in turn to St. Lucia, Martinique, Guadeloupe, and Montserrat, he took at the last-named island two English ships. At Nevis on 7 and 8 June, he engaged the forts and took two more prizes. Thence he went to St. Christopher,

- Cal. of Slate Papers, Dom., 1651-2, 246.

- Warburton, iii. 541.

-4 Ibid. 641-6, 534, 388-9; Cal. of State Papers, Dom., 1651-2, 308-12. 
and finally to the Virgin Islands, where he put into a creek, now known as Cavalier's Harbour, for repairs. Two prizes were found useless and burnt, but on 29 August Rupert got to sea agein with four ships. As before, the weather proved his worst enemy. A gale raged from 13 to 17 September, and in it Prince Maurice, in the Defiance, was lost, together with another smaller vessel, while the Honest Seaman, driven away to leeward and damaged, was wrecked soon after at Porto Pina in Hispanicla. ${ }^{95}$ Rupert alone, in the Swallow, returned to his harbour in the Virgin Islands. Even so he was not beaten ; on 5 October he sailed once more, and took a ship of 10 guns near Montserrat. He spent a fortnight at Guadeloupe, and on 30 October captured three more English ships at Antigua. Returning to Guadeloupe on 7 November, he stayed there till the 20th, save for a brief cruise, in which he took another prize. At last, after a visit to Dominica and Nevis, he returned to his base for a final overhaul. On 12 December he sailed for Europe. At Fayal, on 16 January, he was received by the Portuguese with shots from the forts, and on finding the same reception at St. Michael's, he proceeded direct to France. On 4 March 1653 he entered the harbour of Nantes with five ships, the Swallow and four prizes, and amid the salutes of the fort and of some Dutch ships ended his long and eventful voyage. He sold his ships to Mazarin, and left to join the royalist court. ${ }^{90}$ Lawless as many of his performances undoubtedly were, his voyage of rather more than three years must always rank as a marvellous achievement. Without bases or resources, in the face of a sea-power superior from the first, and steadily increasing, he had yet succeeded in supporting himself and his fleet, and in causing considerable damage to the enemy. ${ }^{97}$

While Rupert was at the Azores and at Cape Blanco, Penn had continued his unenterprising blockade of the Straits of Gibraltar, taking a number of French merchantmen, but making no attempt to pursue his elusive enemy. He did indeed decide on 26 November, when he heard of the loss of the Constant Reformation, that he.would send three ships to attack the remains of the royalist squadron. This idea may have been carried out, but it certainly led to no encounter. On 19 January 1652 Penn raised his blockade and withdrew his ships to Cadiz. ${ }^{98}$ There was now a considerable English force in southern waters. In addition to the eight ships under Penn and the seven under Hall, Captain Appleton had been sent out with the three warships Leopard 48, Bonaventure 44, and Constant Warwick 32. ${ }^{90}$ After

os Warburton, iii. 383.

- Life of Penr, i. 485.

97 A list of shipe known to have pased through his hands will be found in the Appendix.

"Letters and Papers relating to the First Dudeh War, i. 68 . 
meeting Penn in September 1651, ${ }^{100}$ Appleton entered the Mediterranean and cruised here and there on convoy work, using Leghorn as a base, in spite of the fact that Hall had set up friction with the grand duke of Tuscany by taking a French ship in his territorial waters. ${ }^{101}$ Still another squadron, under Captain Badiley, left the Downs on 31 December 1651. It consisted of the Paragon 52, Phoenix 36, and Nightingale 24; the Elizabeth 36 should have been included, but was not ready for sea, though she afterwards followed and relieved the Nightingale. ${ }^{103}$ Badiley met Penn at Cadiz and was apparently accompanied by him as far as the Straits, since on 10 February 1652 Penn was at anchor off Cape Porcus, inside the Mediterranean. ${ }^{103}$ Hall had already been recalled, and on 11 February Penn also left for home. As some substitute for the ships thus recalled, the Worcester 44 and Mermaid 24 were ordered to the Mediterranean; but on 8 March the approach of war with the Dutch made it necessary to cancel their orders, and to leave Appleton's and Badiley's divisions alone in southern waters. ${ }^{104}$

Nearer home the most important events had been taking place in the Scilly Islands. On 15 March 1651 Blake, fresh from the Mediterranean, had been appointed to command the Irish fleet, consisting of the Phoenix, Mayflower, Little President, Providence, Hind, Constant Warwick, Fox, Truelove, Convert, Tenth Whelp, Convertine, and Galliot hoy, with a special detachment for the Shannon, composed of the Portsmouth, Swiftsure, Concord, Fellowship, and Hector. ${ }^{105}$ At the same time Popham was put in command of the fleet in the Downs, while Ayscue was told off to fit out a squadron for the West Indies. All these arrangements were, however, upset by developments in the Scillies. Grenville, the royalist governor, becoming infected with the piratical taint of his party, had begun to molest Dutch ships. At once Tromp was sent with a fleet of 12 sail to stop this. He could get no satisfaction, and proceeded formally to declare war on Grenville. Naturally the parliament decided to intervene; on 1 April they wrote to Ayscue to act under Blake, and ordered the latter to take every possible ship to Scilly. ${ }^{108}$ His instructions were briefly to ask Tromp what he wanted. If he intended anything hurtful to the commonwealth, Blake was to 'require him to

100 Life of Penn, i. 359.

16 Cal. of State Papers, Dom., 1651, 228-9, 483; 1651-2, 17-18; Hit. MSS. Comm. Report 18, App. 1, 622.

10 Letters and Papers relating to the First Dutch War, i. 68; Cal. of State Papers, Dom., 1651-2, 86.

10. Life of Penn, i. 380.

104 Letters and Papers relating to the First Dutch War, i. 68 ; Life of Penn, i. 414.

10' Cal. of State Papers, Dom., 1651, 88.

100 Thurloe, i. 177 ; Whitelock, 17 April 1851 ; Campbell, Lives of the Admirals, ii. 159 ; Heath (second ed.), 288 ; Cal. of State Papers, Dom., 1651, 123. 
desist, and if he persisted, to use the best ways and means he could to enforce him'. He was to say that there was no intention to protect Grenville, and that the Dutch might do what they liked to him, provided always that they had no idea of annexing the Scillies. The Dutch withdrew, visiting Falmouth on their way home, ${ }^{107}$ and Blake began his attack. The smaller islands soon fell, the citadel was bombarded, and a strict blockade was established. Two royalist ships were taken, the Michael 24 and Peter 16, renamed Tresco and Bryer, from the islands where they were captured..$^{108}$ Finally, on 23 May, an agreement was signed whereby the fortress was to be surrendered by 2 June, and the garrison transported with honours to Gelloway. 109

Little had ben happening in the North Sea, where Popham hoisted his flag on 1 April 1651. At first he had nine ships, with his flag in the Hope, but after a fortnight three of his ships were detached to the Dutch coast; on the 17th the Victory joined him. There followed a quiet period, in which the only incident of note was the action of the Defence with two Irish pirates, the Francis and Patrick. On 9 May the Lion and Hopeful Luke, of Hell's fleet, joined from the Straits, and on the l6th a blockade of Dunkirk was begun, but after a month Popham withdrew all save three of his ships, to take charge of a convoy for the North Sea. The ships now with him were the James, Vanguard, Lion, Dragon, and Reserve ; with these he was ordered, after reaching Berwick, to cross the North Sea to the Sound to look for the Swedish fleet, from which hostilities were evidently expected. He shipped his pilots from the Tyne on $7 \mathrm{July}$, but two days later he was recalled. Adding the Happy Entrance to his fleet, he arrived in the Downs on 17 July, to be joined by the Leopard, Reformation, Charles, Seven Brothers, and Greyhound. ${ }^{110}$

Early in August important developments took place. On 6 August Charles Stuart (or Charles II) crossed the Scottish border on the famous march south. At once it became necessary to have a fleet in the North Sea to cut him off from foreign help. Popham would naturally have been given this duty, but on 19 Angust he died; ${ }^{111}$ and as Deane was already on the Scottish coast with the flotilla, Blake had to undertake this important duty. Since the reduction of Scilly he had been in command of the western fleet; with his ships kept in port for reasons of economy. Now he was ordered to bring some of his ships up Channel and take charge of the North Sea fleet, while the squadron to be left

107 Hollandseche Hercurius, 1651, April, p. 49.

101 Cal. of State Papers, Dom., 1651, 180.

10 Ibid. 214-16.

we Leybourne-Popham MSS., 84-98; Cal. of Slate Papers, Dom., 1651, 143, 214.

11 Heath, 303. 
in the Downs was put under Badiley. The crisis did not last long, since on 3 September, when Blake had only just joined his fleet, the battle of Worcester put an end to all danger from the royalists and left the fleet free for other duties. ${ }^{112}$ The Isle of Man and the Channel Islands still held out for Charles II, and they were now the objects of attack. The former surrendered without resistance on 31 October, but the Channel Islands showed a firmer front. Here the attack also began in October, Blake being in command of the fleet, but it was not till 12 December that Elizabeth Castle in Jersey surrendered, while Castle Cornet in Guernsey followed its example on the 17th.

At the same time the royslist cause lost its last position in the colonies. Ayscue, set free by the capitulation of the Scillies, was sent back there on $27 \mathrm{Mry}$, and did not finally leave for the West Indies till 8 August. With the Rainbono 52, Amity 36, Success 30, Ruth 30, Brazil Frigate 24, Malaga Merchant 30, and Increase of London 36, he arrived off Lisbon on 16 August. The Portuguese gave him no opportunity of fighting, and on the 21 st he left again. After a visit to the Cape Verde Islands, where he remained from 8 to 18 September, he arrived off Barbados in the night of 15-16 October. Next morning he sent his 'vice-sdmiral', Captain Pack, into Carlisle Bay with the Amity, Success, and Malaga Merchant. Twelve ships in the bay - eleven of them Dutch-were seized on the charge of trading with the parliament's enemies; two others ran ashore. The forts did practically no damage, although the whole fleet lay in Carlisle Bay all night and most of the next day. ${ }^{113}$ After this Ayscue did very little for some weeks, save to cruise off the island and to exchange letters with the royalist governor, Lord Willoughby of Parham, in the hope of persuading him to surrender. At last, on 22 November, he landed a party, and took a small fort at 'The Hole' on the west side of the island. On 1 December there arrived a fleet of fifteen ships, bound for Virginia to assert the authority of the parliament there. Ayscue tried to use this accession of strength as a means of bringing the royelists to terms, but finding this in vain, he carried out a second and more important landing on 7 December, at Speight's Town, a little north of 'The Hole'. The first attack was successful, but the seamen got out of hand and had to be withdrawn. 'On 14 December the Virginian ships sailed. Ayscue now opened negotiations with the disaffected element ashore. On 3 January 1652 part of the royalist troops mutinied and declared for the parliament, on the 9th Lord Willoughby of Parham asked for terms, and on the 11th the island was definitely surrendered. ${ }^{114}$ In Maroh

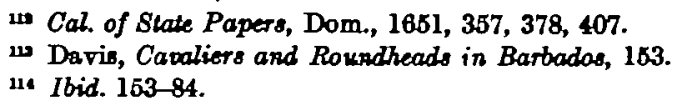


Ayscue left to reduce the remaining islands. This was done without difficulty, and on 25 May 1652 . he arrived at Plymouth with 36 prizes, to find the war with the Dutch in progress. ${ }^{115}$

R. C. ANDERson.

\section{APPENDIX}

Ships belonging to, or takrn by, the Royalist FleEt, 1648-53.

\section{Original Mutineers.}

Constant Reformation 42 lost at sea, 30 September 1651. Sroallow 34 returned to Nantes and sold there, March 1653. Convertine 34 left at Lisbon, October 1650, and handed over to parliament later. Antelope 36 burnt at Helvoetsluys by parliamentarians, April 1649. Satisfaction 26 returned to parliament, November 1648. Roebuck 14 apparently left at Kinsale, October 1649. Crescent 14 returned to parliament, October 1648. Pelican 12 apparently left at Lisbon, October 1650 . Hind 16 returned to parliament, November 1648 .

\section{Additions before leaving Holland.}

Blackmoor Lady 18 joined or taken, July 1648: sold at Lisbon, September 1650. Constant Warroick 30 joined, August 1648: returned to parliament, October 1648. Guinea 30 taken, August 1648: captured, April or May 1649. Love taken, August 1648 : returned to parliament, November 1648. James (formerly the Exchange of Ipsroich) taken, 1648 : left at Kinsale, October 1649. Charles (ex-Hamburger) taken, January 1649 : captured, March 1649. (An English collier) taken, January 1649, and sold at Helvoetsluys.

\section{Additions before reaching Toulon.}

The following were captured by parliamentary warships during Rupert's stay at Kinsale. They all seem to have joined or been taken in the spring of 1649 :

Mary Antrim captured, 14 Februsry 1649. London and Mary and Joseph captured, March 1649. Thomas and Fame of Waterford captured, April or May 1649. Adventure captured, June 1649. Sta. Teresa captured, July 1649.

The following, not otherwise recorded, are mentioned in a manuscript book of accounts of the fleet from 24 February to 11 October 1649, in the present writer's possession :

Ambrose and Charles, Sarah of Bristoll, Desire of Letw, Mary Catch, George of Leith, Good Intent, Culpeper, Antilope, Gloab, Olive Branch, Sarah Bonaventure, Seamew, George of London, Glocester, St. John Baptist, St. Peter of Middlebrough, St. Peter of Ochelling.

11 Heath, 322 ; Whitelock, 29 May 1652. 
The following were apparently added to the fleet at some time in 1649 , before its arrival at Lisbon:

Roebuck 34 taken, November 1649 : captured, 3 November 1650 . Black Kright (or Black Prince) 42 driven ashore and burnt, 4 November 1650. Scatt and Mary, apparently left at Lisbon, October 1650. Second Charles and Henry, wrecked at Carthagena, 5 November 1650.

The following were taken on the way from Lisbon to Toulon :

William of London and Malagonian taken, October 1650 : wrecked at Carthagena, 5 November 1650.'Revenge of Whitehall (ex Marmaduke) taken, 6 November 1650 : mutinied and taken to England, March 1652.

\section{Additions after reaching Toulon.}

Honest Seaman (formerly Jeremy) bought, 1651 : wrecked, September 1652. Loyal Subject (formerly Speedwell) joined, 1651: wrecked, 19 October 1651. St. Michael taken, 1651 : retaken by crew, August or September 1651. Defiance (formerly Friendship) taken, Februsry 1652: lost at sea, September 1652.

There are also records (but without names) of the capture, between May 1651 and November 1652, of one Genoese and four Spanish ships, whose fate is unknown, and of twelve English ships, of which two were burnt in Jaly or August 1652, one lost at sea in September 1652, four sold at Nantes in March 1653, and five came to unknown ends. 